\title{
Evaluating the thermal stability and sorption capacity of several compost chars
}

\author{
L. Tsui, Y. C. Chao, M. A. Juang \& Y. T. Chung \\ Department of Safety, Health and Environmental Engineering, \\ Mingchi University of Technology, Taiwan
}

\begin{abstract}
The chemical composition of compost is much closer to coal when compared with that of agricultural wastes. Since most activated carbon is currently manufactured from coal, it might be easier to produce activated carbon from compost than from other agricultural wastes. In this study, several compost samples were compared for their thermal stability. In addition, sugarcane bagasse samples with three maturities, i.e. 0-month, 1-month, and 6-month, were pyrolyzed to produce carbon chars. The experimental results showed that the thermal stability increased with compost maturity, and thus the highest carbon char yield was obtained from the 6-month compost sample. The analysis of chemical composition showed that the 6-month compost had the highest $\mathrm{C} / \mathrm{H}$ and $\mathrm{C} / \mathrm{O}$ ratios, suggesting it has the greatest hydrophobicity among the three bagasse samples. However, due to its high ash content, the 6-month compost char had less sorption capacity for phenol when compared with other two bagasse chars. Nevertheless, the 6-month compost char had comparable sorption capacity for hydrophobic pollutant naphthalene. The results implied that there might be some advantages of producing compost char as adsorbent for removing hydrophobic pollutants from solution, although more work to enhance the carbon content in the char may still be needed in order to manufacture high quality adsorbent from compost.
\end{abstract}

Keywords: compost char, thermal stability, hydrophobicity, sorption, phenol, naphthalene.

\section{Introduction}

Activated carbons (AC) are one of the most often used adsorbents for controlling environmental pollutants, and they are generally produced from coal. However, 
due to the high cost of coal, there was much research focusing on finding suitable low-cost materials, such as agricultural wastes, to produce AC [1-4]. Several studies have suggested that high surface area AC could be produced from some agricultural wastes, but not all wastes are suitable for $\mathrm{AC}$, mainly due to their high volatile content and low thermal stability. In contrast, most organic wastes can be composted. The composted materials generally show greater thermal stability than their parent compounds $[5,6]$. Therefore, compost could be a more suitable precursor for AC when compared with other agricultural wastes.

Schnitzer and Hoffman [7] compared the van Krevelan diagram for several organic materials. Among the tested organic materials, the $\mathrm{H} / \mathrm{C}$ ratios for cellulose, wood, lignin, humic acid, fulvic acid, and brown coal were around 1.7, $1.5,1.2,1.2,0.9$, and 0.7 , respectively. In addition, their corresponding $\mathrm{O} / \mathrm{C}$ ratios were around $0.9,0.7,0.4,0.5,0.7$, and 0.4 . The data showed that the cellulose has the highest $\mathrm{H} / \mathrm{C}$ and $\mathrm{O} / \mathrm{C}$ ratios, while brown coal has the lowest $\mathrm{H} / \mathrm{C}$ and $\mathrm{O} / \mathrm{C}$ values. The chemical composition of humic acid and fulvic acid in compost was relatively closer to that of brown coal when compared with the cellulose material. The lower $\mathrm{H} / \mathrm{C}$ and $\mathrm{O} / \mathrm{C}$ ratios in humic acid and fulvic acid suggested that compost have greater aromatic structure than cellulose. Because the aromatic portion would generally increase with heating temperature when the agricultural wastes were pyrolyzed [1-3]. The higher aromatic structure in compost suggested that compost have greater thermal stability than other agricultural wastes.

The production of AC usually involved two processes: carbonization and activation. Carbonization (pyrolysis) is sometimes called charring, which consists of heating the feedstock material under a controlled temperature. During carbonization, the carbon content of char increases with temperature accompanied by a simultaneous decrease in oxygen content. The char then undergoes the activation process at elevated temperature to enhance the internal pore structures. Although the carbonization and activation processes can be applied simultaneously, it has been showed that activated carbon produced from two-stage process, i.e. carbonization followed by activation, could have greater surface area when compared with the one-stage process [8]. Hence, to examine the feasibility of making AC from compost, it would be reasonable to study the quality of the first-stage char. In this study, several compost samples were selected to compare their thermal stability. In addition, bagasse compost samples with three different maturities were pyrolyzed to produce carbon chars, and their corresponding chemical characteristics were estimated to evaluate their sorption capacities for different environmental pollutants.

\section{Materials and methods}

\subsection{Compost samples}

Compost samples produced from different feedstock materials were collected at four composting factories in Taiwan. The collected samples were bagasse compost, manure compost, food waste compost, and wasted rice compost. To 
evaluate the effects of compost maturity on the quality of carbon chars, three bagasse compost samples with different maturity were also collected. After the samples were brought back to the laboratory, they were air-dried and screened through a 4-mm sieve. The sieved samples were then heated at $105^{\circ} \mathrm{C}$ overnight prior to chemical characterization or carbonized treatment.

Thermogravimetric (TA) analysis coupled with derivative thermogravity (DTG) analysis of selected compost samples were carried out using a Perkin Elmer DTA/TGA 7 analyzer. The heating rate was set up at $10^{\circ} \mathrm{C} / \mathrm{min}$ from 20 to $800^{\circ} \mathrm{C}$. The chemical composition analysis was conducted only for three selected bagasse compost samples. The ash content was determined by combustion at $800^{\circ} \mathrm{C}$ in a furnace. The elemental composition of $\mathrm{C}, \mathrm{H}, \mathrm{N}$, and $\mathrm{S}$ were measured using Element Analyzer, and the $\mathrm{O}$ content was determined by the difference.

\subsection{Preparation of compost chars}

For each compost sample, a mass of $50 \mathrm{~g}$ sample was put in a 5-cm diameter horizontal quartz tube, and then the tube was heated in a Lindberg type 59344 furnace. The TG analysis showed that most compost samples reached thermal stable at $400^{\circ} \mathrm{C}$, and thus that temperature was selected as the pyrolyzed temperature. The compost samples were heated in flowing ultra-high purity $\mathrm{N}_{2}$ for $1 \mathrm{~h}$, and allowed to cool to room temperature with continuous flowing $\mathrm{N}_{2}$. The remaining sample weight was recorded, and the yield of compost char was defined as the ratio of the weight of the pyrolyzed char to that of the original compost. The $\mathrm{N}_{2}$-BET surface areas of the prepared samples were measured in static volumetric apparatus (Micrometric, model ASAP 2010). Before $\mathrm{N}_{2}$ adsorption, each sample was outgassed $\left(30 \% \mathrm{~N}_{2}\right.$ with He balance) for $45 \mathrm{~min}$ at $120^{\circ} \mathrm{C}$, and nitrogen adsorption measurement was carried at the temperature of liquid nitrogen temperature $(77 \mathrm{~K})$ to estimate the total pore volume $\left(\mathrm{V}_{\text {pore }}\right)$. The surface area $\left(\mathrm{S}_{\mathrm{p}}\right)$ was calculated from the linearlized BET equation, and the micropore volume $\left(\mathrm{V}_{\text {micro }}\right)$ and mesopore surface area were obtained by using the $t$-plot method [9]. The surface area corresponding to the micropores $\left(\mathrm{S}_{\text {micro }}\right)$ was obtained by deducting the mesopore surface area from the total surface area. The chemical compositions of pyrolyzed chars were determined in the same manner as described in the previous section.

\subsection{Adsorption experiments}

Phenol and naphthalene were chosen as adsorbates in this study to evaluate the sorption capacities of the resultant compost chars. The water solubility of phenol and naphthalene was $83 \mathrm{~g} / \mathrm{L}$ and $30 \mathrm{mg} / \mathrm{L}$, respectively. The adsorption experiments were carried out using batch equilibration techniques. The volumes of 100-mL solution with different concentrations of adsorbates were mixed with $0.1 \mathrm{~g}$ compost char in brown serum bottles, and the bottles were sealed with Teflon seal. These bottles were placed in a shaker with the agitation speed of $100 \mathrm{rpm}$ for $24 \mathrm{~h}$. After reaching equilibrium, $10 \mathrm{~mL}$ solution was removed and filtrated using a syringe. The phenol or naphthalene in the filtrate was then 
analyzed using HPLC. The sorption affinities of the compost chars for phenol and naphthalene were evaluated using the Langmuir sorption model as follow:

$$
q_{\text {sorbed }}=\frac{Q_{m} K_{L} C_{\text {aqueous }}}{1+K_{L} C_{\text {aqueous }}}
$$

where $K_{L}$ is the Langmuir sorption coefficient $(\mathrm{mL} / \mathrm{g})$ and $Q_{m}$ the Langmuir capacity parameter $(\mathrm{mg} / \mathrm{g})$.

\section{Results and discussion}

\subsection{Thermal stability of the compost char}

The yields of the compost char obtained from both TG and pyrolysis process are compared in Table 1. The char yields calculated from pyrolysis were smaller when compared with thermal stability measured from TG. There was, however, still a good correlation between the thermal stability and compost char yield, showing that the samples with greater thermal stability would have higher char yield. The less char yield obtained from pyrolysis could result from that the heating tube was not completely air-tied, and thus some oxygen in the air entered the tube and caused greater burn-off of compost char. Among all the samples, bagasse sample had least thermal stability with a char yield of $16 \%$. The rest compost samples had char yields greater than $40 \%$. This observation suggested that compost have greater thermal stability than the bagasse sample.

Table 1: $\quad$ The thermal stability and char yield of different compost samples.

\begin{tabular}{|l|c|c|}
\hline Compost samples & $\begin{array}{c}\text { Thermal stability } \\
\text { from TG }(\%) \\
\left(800^{\circ} \mathrm{C} \text { in } \mathrm{N}_{2}\right)\end{array}$ & $\begin{array}{c}\text { Char yield } \\
\text { from pyrolysis }(\%) \\
\left(400^{\circ} \mathrm{C} \text { in } \mathrm{N}_{2}\right)\end{array}$ \\
\hline Food waste compost & 43 & 40 \\
\hline Wasted rice compost & 43 & 41 \\
\hline Cattle manure compost & 55 & 51 \\
\hline $\begin{array}{l}\text { 6-month bagasse } \\
\text { compost }\end{array}$ & 79 & 68 \\
\hline $\begin{array}{l}\text { 1-month bagasse } \\
\text { compost }\end{array}$ & 57 & 16 \\
\hline $\begin{array}{l}\text { 0-month bagasse } \\
\text { sample }\end{array}$ & 19 & \\
\hline
\end{tabular}

The TG and DTG data of three bagasse samples with different maturity are compared in Figure 1. The TG data showed that 6-month bagasse compost had the greatest thermal stability. In the DTG, there were two distinct peaks at the temperatures of $205^{\circ} \mathrm{C}$ and $285^{\circ} \mathrm{C}$ in the 0 -month sample, corresponding to the weight loss of easily decomposed carbohydrate compounds. The weight loss at temperature $345^{\circ} \mathrm{C}$ was associated with decomposition of aromatic moieties [6]. 

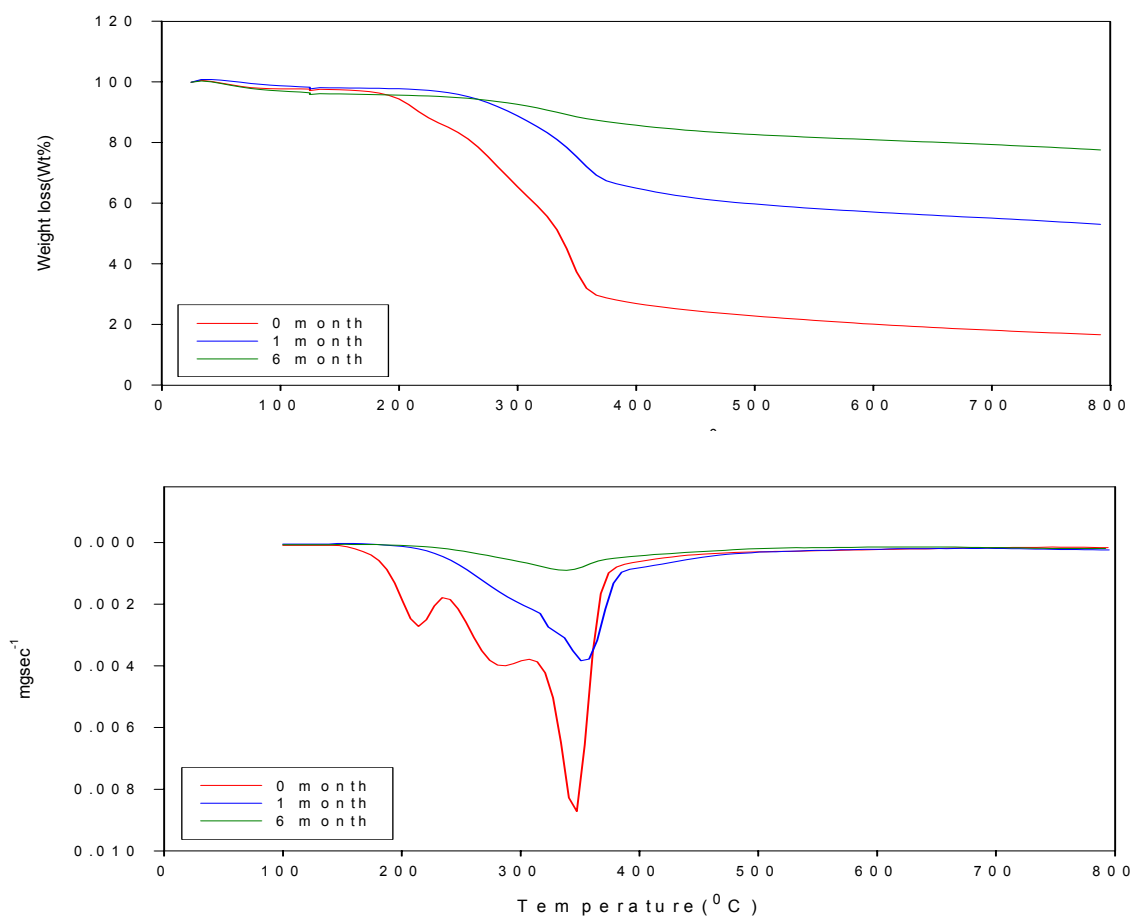

Figure 1: TG and DTG curves of three bagasse samples with different maturity.

\subsection{The characteristics of pyrolyzed chars}

Although the 6-month compost sample had the highest thermal stability, the analysis of chemical element composition suggested that the high thermal stability of that sample was mostly due to its high ash content (Table 2). It should be noticed that around $15 \%$ of pig manure was mixed with bagasse sample at the beginning of composting process. The inorganic composition in manure could act as catalyst to enhance the thermal decomposition of compost during pyrolysis [10], and thus further promote the mineralization of organic compositions from compost. Therefore, chars obtained from the compost samples showed lesser carbon content when compared with that obtained from bagasse sample.

Before the samples were pyrolyzed, the 1-month compost had the highest $\mathrm{C} / \mathrm{H}$ ratio and the lowest $\mathrm{C} / \mathrm{O}$ ratio. After the sample was pyrolyzed; however, there was an increasing trend for both $\mathrm{C} / \mathrm{H}$ and $\mathrm{C} / \mathrm{O}$ ratios with compost maturity (Table 2). The highest $\mathrm{C} / \mathrm{H}$ and $\mathrm{C} / \mathrm{O}$ ratios in 6-month compost char suggested that sample having the largest hydrophobicity among the three pyrolyzed bagasse samples. 
Table 2: $\quad$ The chemical composition of three selected bagasse samples.

\begin{tabular}{|l|c|c|c|c|c|c|c|c|}
\hline Samples & $\begin{array}{c}\mathrm{C} \\
(\%)\end{array}$ & $\begin{array}{c}\mathrm{N} \\
(\%)\end{array}$ & $\begin{array}{c}\mathrm{H} \\
(\%)\end{array}$ & $\begin{array}{c}\mathrm{S} \\
(\%)\end{array}$ & $\begin{array}{c}\mathrm{O} \\
(\%)\end{array}$ & $\begin{array}{c}\text { Ash } \\
(\%)\end{array}$ & $\begin{array}{c}\mathrm{C} / \mathrm{H} \\
(\text { atomic } \\
\text { ratio })\end{array}$ & $\begin{array}{c}\mathrm{C} / \mathrm{O} \\
(\text { atomic } \\
\text { ratio }\end{array}$ \\
\hline $\begin{array}{l}\text { 6-month bagasse } \\
\text { compost sample }\end{array}$ & 28.96 & 1.56 & 4.16 & 0.93 & 18.16 & 46.23 & 0.58 & 2.13 \\
\hline $\begin{array}{l}\text { 6-month bagasse } \\
\text { compost char }\end{array}$ & 36.78 & 0.83 & 0.34 & 0.20 & 0.02 & 61.83 & 9.01 & 2446.7 \\
\hline $\begin{array}{l}\text { 1-month bagasse } \\
\text { compost sample }\end{array}$ & 32.84 & 1.72 & 3.42 & 0.47 & 27.11 & 29.09 & 0.79 & 1.61 \\
\hline $\begin{array}{l}\text { 1-month bagasse } \\
\text { compost char }\end{array}$ & 44.80 & 1.23 & 0.62 & 0.22 & 2.28 & 51.85 & 6.02 & 26.19 \\
\hline $\begin{array}{l}\text { 0-month bagasse } \\
\text { sample }\end{array}$ & 51.41 & 0.69 & 8.84 & 1.31 & 35.86 & 1.89 & 0.48 & 1.91 \\
\hline $\begin{array}{l}\text { 0-month bagasse } \\
\text { char }\end{array}$ & 74.96 & 0.12 & 1.09 & 0.21 & 17.57 & 6.05 & 5.73 & 5.71 \\
\hline
\end{tabular}

The $\mathrm{N}_{2}$-BET surface areas of the three selected bagasse chars are compared in Table 3 . When the bagasse was pyrolyzed at $400^{\circ} \mathrm{C}$ in nitrogen, the surface area was generally low with a maximum value of $7.81 \mathrm{~m}^{2} / \mathrm{g}$. This observation was consistent with other studies showing that the surface area of natural organic matter was small when measured using $\mathrm{N}_{2}$-BET method [11-13]. However, those studies have pointed out that the low measured surface area could result from the observations that the pores within the chars were extremely small and deadended, so the nitrogen molecules could not access to those pores at the temperature of liquid nitrogen. The 6-month compost char had the largest surface area among the three char samples, but the measured surface area could partly come from its ash content (Table 2).

Table 3: $\quad$ Physical properties of bagasse chars.

\begin{tabular}{|l|c|c|c|c|}
\hline Char samples & $\begin{array}{c}\mathrm{S}_{\mathrm{p}} \\
\left(\mathrm{m}^{2} / \mathrm{g}\right)\end{array}$ & $\begin{array}{c}\mathrm{V}_{\mathrm{p}} \\
\left(\mathrm{cm}^{3} / \mathrm{g}\right)\end{array}$ & $\mathrm{S}_{\text {micro }} / \mathrm{S}_{\mathrm{p}}$ & $\mathrm{V}_{\text {micro }} / \mathrm{V}_{\mathrm{p}}$ \\
\hline 0-month bagasse char & 2.57 & 0.0035 & 0.369 & 0.1065 \\
\hline $\begin{array}{l}\text { 1-month bagasse } \\
\text { compost char }\end{array}$ & 5.22 & 0.0126 & 0.015 & 0.0008 \\
\hline $\begin{array}{l}\text { 6-month bagasse } \\
\text { compost char }\end{array}$ & 7.81 & 0.0201 & 0.047 & 0.0049 \\
\hline
\end{tabular}

\subsection{The sorption behaviours of carbon chars}

The sorption capacities for phenol and naphthalene of the three carbon chars are compared in Table 4. In general, carbon chars had much greater sorption capacities for naphthalene than for phenol, because the solubility of naphthalene was much smaller. Among the three char samples, the 0-month bagasse char had the largest sorption capacities for both phenol and naphthalene, mainly due to its high carbon content (Table 2). However, when calculating the sorption capacities on per gram of raw compost base, 0 -month bagasse sample had the least sorption 
measurements, attributable to its low char yield of $16 \%$ (Table 1 ). The maximum sorption capacity for naphthalene by 6-month compost char was $252 \mathrm{mg} / \mathrm{g}$, which was close to that of 0 -month bagasse char, even though the 6-month char sample had less than half of carbon content when compared with the 0-month char sample. The comparable sorption capacity for naphthalene by 6 -month char sample could result from its high hydrophobicity, as analyzed by its chemical composition (Table 2).

Table 4: The sorption parameters for phenol and naphthalene by different bagasse samples.

\begin{tabular}{|l|c|c|c|c|c|c|}
\hline Samples & \multicolumn{3}{|c|}{ Phenol } & \multicolumn{3}{c|}{ Naphthalene } \\
\hline & $\begin{array}{c}\mathrm{Qm} \\
(\mathrm{mg} / \mathrm{g})\end{array}$ & $\begin{array}{c}\mathrm{K}_{\mathrm{L}} \\
(\mathrm{mL} / \mathrm{g})\end{array}$ & $\mathrm{R}^{2}$ & $\begin{array}{c}\mathrm{Qm} \\
(\mathrm{mg} / \mathrm{g})\end{array}$ & $\begin{array}{c}\mathrm{K}_{\mathrm{L}} \\
(\mathrm{mL} / \mathrm{g})\end{array}$ & $\mathrm{R}^{2}$ \\
\hline 0-month bagasse char & 8.3 & 0.34 & 0.97 & 263 & 6.8 & 0.95 \\
\hline $\begin{array}{l}\text { 0-month bagasse char } \\
\text { based on per gram of } \\
\text { raw bagasse }\end{array}$ & 1.33 & & & 42.08 & & \\
\hline $\begin{array}{l}\text { 1-month bagasse } \\
\text { compost char }\end{array}$ & 6.5 & 0.65 & 0.96 & 197 & 4.2 & 0.92 \\
\hline $\begin{array}{l}\text { 1-month bagasse char } \\
\text { based on per gram of } \\
\text { raw compost }\end{array}$ & 3.31 & & & 100.47 & & \\
\hline $\begin{array}{l}\text { 6-month bagasse } \\
\text { compost char }\end{array}$ & 4.2 & 0.57 & 0.92 & 252 & 7.1 & 0.93 \\
\hline $\begin{array}{l}\text { 6-month bagasse char } \\
\text { based on per gram of } \\
\text { raw compost }\end{array}$ & 2.86 & & & 171.36 & & \\
\hline
\end{tabular}

It should be noted that the pyrolyzed temperature was set at $400^{\circ} \mathrm{C}$ in this study, and thus the 0 -month bagasse char had low ash content of $6 \%$. If the samples are pyrolyzed at a higher temperature, it is likely that the ash content in the 0-month bagasse char would increase more significantly when compared with that of 6-month compost char sample. The current study has demonstrated that 6-month compost char had comparable sorption capacity for hydrophobic pollutant naphthalene. The results also showed that the compost chars had greater sorption capacities for both phenol and naphthalene based on per gram of raw compost sample. However, due to its high ash content, the compost char had lesser carbon content when compared with carbon char derived directly from bagasse sample. Therefore, in order to demonstrate the advantages of using compost char for removing hydrophobic pollutant from solution, further research of concentrating carbon content in the compost char is needed.

\section{Conclusion}

This study demonstrated that the thermal stability increased with compost maturity, so greater yields of compost char were obtained when compared with 
carbon char derived directly from bagasse. In addition, the compost chars had greater hydrophobicity than the bagasse carbon char, and thus it had greater sorption capacity for hydrophobic pollutant on per gram of raw compost base. However, the compost char had large ash content, which neutralize its advantage of hydrophobicity. Therefore, although there are some potential advantages in producing char from compost, more work is still needed in order to enhance the carbon content in the compost char.

\section{References}

[1] Sharma, R.K., Wooten, J.B., Baliga, V.L., Lin, X., Chan, W.G., \& Hajaligol, M.R., Characterization of chars from pyrolysis of lignin. Fuel, 83, pp. 1469-1482, 2004.

[2] Carrott, S.P.J.M., \& M.M.L.R. Carrott, Lignin-from natural adsorbent to activated carbon: A review. Bioresource Technology, 98, pp. 2301-2312, 2007.

[3] Dias, J. M., Alvim-Ferraz' M.C.M., Almeida, M. F., Rivera-Utrilla, J., \& M. Sánchez-Polo, Waste materials for activated carbon preparation and its use in aqueous-phase treatment: A review. Journal of Environmental Management, 85, pp. 833-846, 2007.

[4] Ioannidou, O, \& Zabaniotou A. Agricultural residues as precursors for activated carbon production-A review. Renewable and Sustainable Energy Reviews, 11, pp. 1966-2005.

[5] Dell'Abate, M. T., Canali, S., Trinchera, A., Benedetti, A., \& Sequi, P., Thermal analysis in the evaluation of compost stability: a comparison with humification parameters. Nutrient Cycling Agroecosystem, 51, pp. 217 224, 1998.

[6] Pietro, M. \& Paola, C., Thermal analysis for the evaluation of the organic matter evolution during municipal solid waste aerobic composting process. Thermochim Acta, 413, pp. 209-214, 2004.

[7] Schnitzer, M. \& Hoffman, I., Pyrolysis of soil organic matter. Soil Science Society of America Proceeding, 28, pp. 520-525, 1964.

[8] Diao, Y, Walawender, W.P., \& Fan. L.T., Activated carbon prepared from phosphoric acid activation of grain sorghum. Bioresource Technology, 81, pp. 45-52, 2002.

[9] Wu, F.C., Tseng, R.L., Hu, C.C., \& Wang, C.C., The capacitive characteristics of activated carbons-comparisons of the activated methods on the pore structure and electrolyte on the capacitive performance. Journal of Power Sources, 159, pp. 1532-1542, 2006.

[10] Fengel, D. \& Wegener G., Wood: Chemistry Ultrastructure, Reactions, New York: Walter de Gruyter, pp. 132-181, 1984.

[11] De Jonge, H., \& Mittelmeijer-Hazeleger. M.C., Adsorption of $\mathrm{CO}_{2}$ and $\mathrm{N}_{2}$ on soil organic matter: nature of porosity, surface area, and diffusion mechanisms. Environmental Science \& Technology, 30, pp. 4008-4013, 1996. 
[12] Kaiser, R. \& Guggenberger, G., Mineral surfaces and soil organic matter. Europe Journal of Soil Science, 54, pp. 219-236, 2003.

[13] Makris K.C., Sarkar, D., Datta, R., Ravikovitch, P.I., \& Neimark, A.V., Using nitrogen and carbon dioxide molecules to probe $\operatorname{arsenic}(\mathrm{V})$ bioaccessibility in soils Environmental Science \& Technology, 40, pp. 7732-7738, 2006. 